\title{
On Doing Intellectual Work: Grasping the Power of the Gestalt
}

\section{Rita Weathersby}

All of us do intellectual work as part of the common process of making sense of our experience. We set forth ideas, attempt to verify and extend them, and experiment with alternative conceptualizations. Inevitably we create a frame of reference which provides a context for what we say and which gives grounds for judging its validity. It is this process of context setting that seems most crucial to me, given my approach to intellectual work and to joining the worlds of contemplation and action.

I am a professor, not a faculty developer. Yet I am inescapably a faculty developer because the crux of my profession is fostering beneficial changes in others - in managers, in situations, and in students. I have focused my recent work on adult development, and on the potential for creating transformative organizational environments. This frame of reference has become my context for interpreting events; for example, when I evaluate a college's responsiveness to adult students or a company's responsibility for the career development of its employees. My work is synthetic and theoretical, yet also immediately practical because an understanding of developmental processes guides my day-to-day decisions.

Overall, I've come to envision my central task as that of enabling myself and others to grasp the power of a transformative gestalt, a way of "seeing" a situation differently and more adequately. The corollary 
task is to act more effectively from that changed perspective. Thus, my role as a scholar is no different from my roles as teacher or organizational consultant. The heart of the task lies in working with my own and others' processes of experiencing and of fostering qualitative shifts in how sense is made of that experience.

\section{A Transformative Gestalt}

It's not surprising, as I reflect on it, that transformation is my central issue and that I am searching intuitively for patterns to explain my own and others' experience. I am a divergent thinker whose strengths are the ability to see multiple perspectives, to grasp issues imaginatively and intuitively, to embrace emotion and concretences, and to stand back and look again, hopefully "seeing" more than others see. In my fondest fantasies I envision myself as an artist or magician seizing the power of an inward perceptual thread to transform outer reality. I am drawn to theories of transformation. I am fascinated with learning methodologies that purport to change people's perspectives. I have experienced perspective shifts, the embracing of developmental tasks, and the powerful impact of group processes and personal learning methodologies. I have found relationships and environments that fostered my own development and those that hindered it. I choose to spend my time and energy in activities that create the potential for "significant learning", to use Carl Roger's phrase, in myself and society. That is the core of my intellectual work. In sum, that is my work.

If my major interest is in developmental transformation, corollary interests are promoting perceptual complexity and cultivating the skill of moving from complex perceptions to actions informed by that complexity. I think of this as developmental complexity because greater awareness, differentiated and reintegrated at higher levels, characterizes state theories of adult development (Bartunek, Gordon, \& Weathersby, 1980a; Kchlberg \& Mayer, 1972; Loevinger \& Redmore, 1970; Loevinger, 1976) and also characterizes applications of gestalt psychology to individual and organizational change (Polster \& Polster, 1973). I have tended to focus on the possibility of personal change in institutional contexts. But, I am after the gestalt here, and 
in the foreground is developmental transformation, a qualitative shift in perspective, supported by cultivating and articulating the experiencing process. That "experiencing process" can belong to an individual, a group, or an institution. The pressing questions for me, at this moment, lie in identifying the stages, patterns, structures and pathways of growth that enable us to cope with change and to transform our environments. For example, what are the characteristics of organizational environments that support self-actualization for individuals? How can we enable individuals and institutions to become who they best are in a complex and constantly changing world?

\section{What Led Me to These Questions}

These questions are the result of a career spanning fifteen years and twelve institutions. I have moved from educational research and development, to program administration at the federal level, to group training and counseling, to consultant work with academic institutions around issues of adult learning and professional education, to college teaching and my present position in the organizational behavior group at the University of New Hampshire. My career continues to require constant changes of perspective.

The forces shaping my work are both intrinsic and extrinsic. Extrinsically, there are interesting job opportunities and worthwhile institutional concerns. For example, developing materials for teachers' classroom behavior (at the Far West Laboratory for Educational Research and Development in San Francisco); institutionalizing competency-based standards for training and assessment of child care professionals (at the Office of Child Development/DHEW in Washington, D.C.) which, in effect, created a new professional role; facilitating academic planning for a newly-established graduate school of psychology dedicated to creating new options and roles for mental health professionals (at the Massachusetts School for Professional Psychology); or consulting with a national network of higher education institutions about adult development and program design (sponsored by the Fund for the Improvement for Postsecondary Education). Whatever the context and immediate task, however, the core of the work that invariably excites me is implementing a new vision. Invari- 
ably, I am involved with efforts to change people and institutions. Usually, I am seeking ways to articulate and implement changes of perspective. The components of the change are definitions of purpose, tasks and roles, and enlarged perceptions of what is worth noticing and responding to in a situation.

\section{Research as Perspective Transformation}

Research for me involves enlarging a process of personal search and also search for a transformational idea or context. Let me give several examples.

At Wheelock College in Boston, I had the opportunity to compare adults' abilities to perceive themselves as self-directed learners with their skill in responding to individual differences and the developmental needs of young children. The adults were enrolled in an innovative competency-based child care staff training program. The opportunity and interest grew out of my experience inaugurating the program from the federal level. The research was shaped by my conviction that adults could best respond to developmental differences in young children if they could perceive themselves developmentally and could articulate their own processes of learning.

Formulating the research in this way was an important shift in perspective. At that time I was vitally concerned with self-directed learning in my own life. What I did in this study was shaped by real interest, by asking myself what I really wanted to know for myself that might have profound implications also for others. The results confirmed my conviction and had some immediate implications for the design and eventual effectiveness of the program. However, the power here is in the gestalt - the idea itself: the necessity for adults to have complex and differentiated perceptions of themselves and their learning processes if they are to create any fundamental changes in institutions. Another study of the same program, this one from an institutional and policy perspective (Weathersby, 1974) focused on the idea of this new professional role and the possibility of institutionalizing it.

A study more relevant to faculty development efforts is my study of students in the Adult Degree Program of Goddard College. In a 
previous review of the literature (Weathersby, 1977), I placed individuals in the three developmental sequences of that framework-life cycle stages, structural developmental stages, and learning style. I then investigated how each dimension of development shaped a student's perceptions of the program, reasons for attending, and awareness of using education to support a life transition or personal growth.

The intrinsic reasons for the study were compelling. I was fascinated by life span psychology applied to adults: by the work of Daniel Levinson (1978), Roger Gould (1978), and George Vaillant (1977) in tracing successive issues and developmental tasks of the life cycle, by Jane Loevinger's (Loevinger \& Redmore, 1970; Loevinger, 1976) description of stages of ego development, and by William Perry's $(1970 ; 1981)$ scheme tracing students' responses to a college environment in their intellectual progress from dualism to multiciplicity and relative thinking. I knew that graduate study had changed my own inner life, and I understood it in the context of these developmental theories. I wanted to articulate this process for others. Extrinsically, no one had this kind of data on adult students. And, more importantly, I had a collaborator in Jill Mattuck Tarule, at that time a faculty member in the program. She used some of the same data in conjunction with clinical interviews to outline steps in a process of inner transformation that enabled movement within and across the stages (Tarule, 1980).

The results of my study showed clearly the effect of an individual's place in these developmental sequences in determining what is learned, how, and what meaning is assigned to it. Subsequent articles have elaborated these results, suggesting implications for higher education (Weathersby 1980, 1981; Weathersby \& Tarule, 1980). What I personally value about this work is the context form which my research questions arose - the assumption, now validated, that an individual's capacity for transformational learning is shaped by the developmental sequences of adulthood; and that an educational institution can play a facilitative role in what I would call life transitions and developmental change.

My work in adult development led to a three-year consultancy with a national network of adult projects funded by the Fund for the Improvement of Postsecondary Education. Here the emphasis was on 
refining the dialogue among informed practitioners and articulating useful constructs to connect research and theory about adults with program design. This was a multi-institutional network, with individuals joining and leaving at various points. The network created a base for mutual support and professional renewal. We convened at twiceyearly working conferences at which we discussed baseline data on students in each program, taught each other our diverse research perspectives, discussed case studies of individual students, and articulated our assumptions about designing programs for adults. We wrote individually and collaboratively in several formats (Bartunek, Gordon, \& Weathersby, 1979; Greenburg, Bergquist, \& O'Donnell, 1989; Tarule \& Weathersby, 1979) and also convened a national conference on adult development and program design to share the results of our efforts. FIPSE offered this opportunity in the form of funding and organizational focus for the dialogue. The network maintained itself through collaborative working relationships that allowed each individual and program its uniqueness in contributing to the common effort. Again, in this work I value the context: collaborative learning created the basis for institutional improvement.

Recently, I began a study of women business owners in New Hampshire. I started with baseline data: How many are there? What kinds of businesses? What obstacles do they face? What kinds of learning accompany the role? I began the study in response to the creation of a Small Business Development Program within the University System, and the fact that I had been appointed to a faculty committee overseeing the effort. The program provided me with a small grant and released time from teaching. The Whittemore School has provided the services of several graduate research assistants. These are incentives but the idea that excites me, and my purpose for the study, is creating visibility for women in business: documenting their presence, articulating their experience, and creating an awareness of their educational needs. The study is a small intervention intended to raise the consciousness of individuals and agencies throughout the state. One result is a Directory of Women-Owned Businesses in New Hampshire (Bartunek, Gordon, \& Weathersby, 1980b). The directory gives women business owners access to them. Again, the process of articulating someone's experience more complexly, and creating the 
possibility that they and others will change their attitudes or be moved to action, is what satisfies me.

These same concerns lead to intellectual work in conjunction with my teaching. I seek to "teach developmentally", which means designing instruction to "pull" developmental change. Currently, my students are MBAs in a course on human behavior in organizations and graduating seniors and experienced working women in a seminar on women in management. I want them to perceive their current and future work situations more complexly, and to be able to consciously shape their actions in line with their highest goals and developmental values. I want them to be able to adapt to organizational situations as they are, and to transform them, using their own processes of search as the basis for action.

\section{Gathering and Analyzing Data}

Given my goals, research is not a detached process. It is a collaborative process, involving others in elaborating, confirming and disconfirming interpretations. In formal studies I tend to use a mix of research procedures: standardized tests with scoring systems that have reliability and validity (e.g., Loevinger's Sentence Completion Test for ego development or Kolb's Learning Style Inventory) and my own questionnaires with some factual items that can be quantified and some short open-ended questions that have to be content-analyzed. However, I'm not satisfied until these are supplemented by face-to-face interviews and participant observation. Studying Goddard's Adult Degree Program, for example, I lived in the student dormitory through two group residencies and talked nonstop with anyone who would talk to me (and there was always someone) through breakfast, lunch, dinner, and parties. Similarly, I will not feel satisfied that I understand the situation of women business owners until I add to my initial survey data some individual or group interviews.

The point at issue here is what constitutes data, and how one arrives at the context for interpreting it. Because much of my work involves context setting, data gathering and analysis is not necessarily the central concern. For example, in creating a conceptual framework for synthesizing dimensions of adult development my concerns were 
identifying central ideas about stages, sequences, levels and developmental change in research from a variety of disciplinary traditions and stating their commonalities while respecting their differences. The result was a broader, more elaborated concept of development and, thus, framework for application. What is of concern to me in much of my work is the validity of the synthesis as a context for action.

\section{Relevance and Cooperation}

Trust is important in the relevance of research to people's lives. Eliciting cooperation has not been a problem because I ask about people's experience and learning process, their assumptions in doing what they are doing, and their use of institutions for their own purposes. Establishing trust is a prerequisite which I usually deal with by saying clearly what it is I want to know, and asking for help in learning about it. I generally ask questions that people like to answer and need to answer for themselves. The experience of completing a questionnaire, or being interviewed, or sharing views with others can be rewarding itself if the topic is relevant. In addition to creating a mutually satisfying process, I repay people with thanks and with concrete outcomes if I can: for example, inclusion in the Directory of New Hampshire Women Business Owners or scores on the Learning Style Inventory and help in interpreting them. Collaborating with others in interpreting and applying results is for me a joy and a necessity. Perspective transformation is a shared activity.

\section{Standards of Scholarship}

My work is interdisciplinary, applied, theoretical, eclectic and synthetic. I use methodologies from social and clinical psychology, anthropology and organizational behavior: action research, survey research, psychological tests, individual and group interviews and participant observation. The end goal, however, is a synthesis beyond the methodologies. This creates within myself a constant source of tension. I imagine multiple audiences, and there is always some audience for whom the work is too theoretical, too applied, or whose assumptions about the nature of knowledge have been violated. 
A recent paper provides useful illustration. Jean Bartunek and Judith Gordon, professors of management at Boston College, and I have collaboratively written a paper called "Teaching Administrators to Complicate Themselves" (Bartunek, Gordon, \& Weathersby, 1980a). The paper grew out of an intensive workshop we conducted with national administrative teams from the Religious Order of the Sacred Heart. In the workshop, we designed a process to explore applications of adult development theory, career development, and notions of organizational socialization and change to the order's practices of inducting new members, and guiding their work choices and personal development over a lifetime. Our paper, which describes the rationale and activities of the workshop, is simultaneously too "theoretical" (but we made a conceptual breakthrough in relating theories of cognitive complexity and problem solving to stage theories of adult and organizational development), too "programmatic" (we describe our teaching designs), and not "empirical" enough (we couldn't measure the outcomes of our workshop precisely enough to publish in a journal of social change research). Yet the workshop was phenomenally successful, and I "saw" something happen. We created a context and series of activities that enabled participants to see the religious issue of "formation" from the perspective of several recent theories of individual and organizational development. This perspective change created a new base for policy and problem solving. Several administrative initiatives were changed in tone and substance because of this new understanding.

In my judgement this is good work. In terms of standards, I require the best I can do within my own framework. I want a sense that what I do and write is on the "cutting edge" of a vision. Or, alternatively, that it illumines a vision that the people with whom I'm working don't yet have, even if others have encounter similar notions long ago. Further, I have developed a sense of humor and humility about my sense of standards. What kind of academic standards can you have for transformational magic? The images have to cohere, and communicate - if someone else says "aha," or uses my work, or it creates relationships for me and evolves into still more work that has the feel of integrity, I am satisfied. 


\section{Influencing Other Researchers and Practitioners}

My attempts to influence others arise from my conviction that results do not influence apart from a network of relationships, or the power of an idea. Results do not influence me. Relationships and ideas do.

I respond to requests to speak at meetings, collaborate on workshops, and write for informal forums that I know will have wide distribution - for example, the annual meetings of the American Association for Higher Education or the Academy of Management. I also seek those opportunities out, and design them into projects that I undertake. I consult on the phone with people who are interested in something I have done. I respond poorly, and very late, to letters. I respond to requests for copies of articles I have on hand. I feel pleased when someone uses my framework, or replicates a study, or bases a workshop on my materials. Otherwise, I am singularly neglectful of attempts to influence others with the results of my work. In my mind, ideas and contexts speak for themselves.

\section{Protecting Time for Intellectual Work}

Merging the worlds of action and disciplined inquiry is a frustration as well as a choice. It is difficult to find the time and space for intellectual work when there is so much else to do.

I should do better; I teach time management seminars as part of my business school faculty role. I plan two days a week for intellectual work, but that is not enough and I have difficulty protecting them. Also, I involve myself in so many things simultaneously (at this moment: two papers, an ongoing study, a seminar series, an ongoing consulting commitment and two one-time workshops) that progress on each is limited. I think I'm saved in this regard because I make it a point to meet commitments. Recently I have been writing, speaking, or developing workshops according to specific deadlines. With each new project, I try to push my thinking a little further. But I do not have time to really pursue intellectual work as I'd like. Partly, I prefer to work collaboratively, and that takes more time and effort.

I have more time than others, perhaps, because I am single and without dependents. I can be extremely flexible in how I use my time. 
Space is also no problem. I have an office at home and one at the university. Psychological space is more of an issue. I need large blocks of time, some pressure-filled and others free of pressure, and also colleagues who share similar visions and struggles.

In terms of "how to," I think I protect myself again through relationships at home and across the country. I have people I can call when I need a quick critique, or a opinion. Usually, they are the same people who ask me to collaborate on an event or an article. Because I make good on commitments to people, my intellectual work gets done, and my life is richer for it.

\section{References}

Bartunek, J.M., Gordon, J.R., \& Weathersby, R.P. Designing for development: Four programs for adult undergraduates. A working report of programs at Clark University, Loretto Heights College, Mary Baldwin College and the Vermont State Colleges. Written collaboratively by a network of adult projects sponsored in part by the Fund for the Improvement of Postsecondary Education/DHEW, 1979. (Available through ERIC System: HE 012 287, June RIE MF - \$0.98. PC - \$4.46.)

Bartunek, J.M., Gordon, J.R., \& Weathersby, R.P. Teaching administrators to complicate themselves. Paper presented at the Annual Meeting of the Academy of Management, Detroit, August 1980(a). (Available from the authors.)

Bartunek, J.M., Gondon, J.R., \$ Weathersby, R.P. Directory of women-owned businesses in New Hampshire. Small Business Development Program, University of New Hampshire, in conjunction with the Whittemore School of Business and Economics. September 1980(b).

Gould, R.L. Transformations: Growth and change in adult life. New York: Simon and Schuster, 1978.

Greenburg, E., Bergquist, W., \& O'Donnell, K. (Eds.) Educating learners of all ages. New Directions in Higher Education, No. 29, 1980.

Kohlberg, L., \& Mayer, R. Development as the aim of education. Hanard Educational Review, 1972, 42, 449-496.

Levinson, D.J. The seasons of a man's life. New York: Alfred A. Knoff, 1978.

Loevinger, J. Ego development: Conceptions and theories. San Francisco: Jossey-Bass, 1976.

Loevinger, J., \& Redmore, C. Measuring ego development. Vols. I and II. San Francisco: Jossey-Bass, 1970.

Perry, W.G. Cognitive and ethical growth: The making of meaning. In A.W. Chickering \& Associates, The modern American college. San Francisco: Jossey-Bass, 1981.

Polster, E., \& Polster, M. Gestalt therapy integrated. New York: Brunner/Makel, 1973. 
Tarule, J.M. The process of developmental transformation: Steps toward change. New Directions in Higher Education, No. 29, 1980.

Tarule, J.M., \& Weathersby, R.P. Adult development and adult learning styles: The message for nontraditional graduate programs. Journal of Alternative Higher Education, 1979, 4 (1).

Vaillant, G.E. Adaption to life. Boston: Little, Brown, 1977.

Weathersby, R.P. The child development associate program: Case study of a federal initiative in social intervention. Unpublished manuscript, Harvard Graduate School of Education, 1974.

Weathersby, R.P. A synthesis of research and theory on adult development - Its implications for adult learning and postsecondary education. Harvard Graduate School of Education, 1976. (Available through the Harvard Graduate School of Education Library and the ERIC system: ED-165-678 and HE 010-970, June 1979 RIE).

Weathersby, R.P. A developmental perspective on adults' uses of formal education. Doctoral dissertation. Harvard Graduate School of Education, 1977. (Available at the Harvard Graduate School of Education Library and through University Microfilms International, P.O. Box 1764, Ann Arbor, Michigan 48106.)

Weathersby, R.P. Education for adult development: the components of qualitative change. New Directions in Higher Education, No.29, 1980.

Weathersby, R.P. Ego development. In A.W. Chickering \& Associates, The modern American college. San Francisco: Jossey-Bass, 1981.

Weathersby, R.P., \& Tarule, J.M. Adult development: Implications for Higher Education. AAHE - ERIC/Higher Education Research Report No. 4, 1980. (Available from the American Association for Higher Education, One Dupont Circle, Suite 780, Washington, D.C. $\$ 4.00, \$ 3.00$ for AAHE members.) 